\title{
Pengaruh Kualitas Produk dan Kualitas Pelayanan terhadap Kepuasan Konsumen (Studi Kasus Pada Coffee Shop di Kota Bogor)
}

\section{The Effect of Product Quality and Service Quality on Costumer Satisfaction (A Case Study of Coffee Shops in Bogor City)}

\author{
Mush'ab Ihsan Mu'tashim ${ }^{1}$, Alim Setiawan Slamet ${ }^{1 *}$ \\ ${ }^{1)}$ Departemen Manajemen, Fakultas Ekonomi dan Manajemen, IPB Kampus Dramaga Bogor 16680
}

\begin{abstract}
This study aims to determine the effect of product quality and service quality on the customer satisfaction at Ngopi Doeloe, Popolo Coffee, Ranin Coffee House, Starbucks Coffee, The Coffee Bean \& Tea Leaf, and JCo Donuts \& Coffee Bogor. This research conducted by distributing questionnaires to 366 coffee shop visitors. Data analysis method used in this research is Structural Equation Model (SEM). Overall, in this reasearch found that product quality and service quality have impact on costumer satisfaction, but for the low income respondent (below Rp 3.000.000,00) the product quality variable have no impact on costumer satisfaction.
\end{abstract}

Keywords: coffee shop, costumer satisfaction, product quality and service quality.

\begin{abstract}
ABSTRAK
Penelitian ini bertujuan untuk mengetahui pengaruh kualitas produk dan kualitas pelayanan terhadap kepuasan konsumen pada pelanggan Ngopi Doeloe, Popolo Coffee, Rumah Kopi Ranin, Starbucks Coffee, The Coffee Bean \& Tea Leaf, dan JCo Donuts \& Coffee Bogor. Penelitian ini dilakukan dengan penyebaran kuesioner kepada 366 pengunjung coffee shop. Metode yang digunakan dalam penelitian ini adalah Structural Equation Model (SEM). Secara keseluruhan ditemukan bahwa variabel kualitas produk dan kualitas pelayanan berpengaruh terhadap kepuasan konsumen, akan tetapi pada responden dengan pendapatan rendah (dibawah Rp 3.000.000,00), kualitas produk tidak memiliki pengaruh terhadap kepuasan konsumen.
\end{abstract}

Kata Kunci: coffee shop, kualitas produk dan kualitas pelayanan, kepuasan konsumen.

*Corresponding author

Alamat e-mail: alimss@ apps.ipb.ac.id 


\section{PENDAHULUAN}

Di Indonesia kopi merupakan produk unggulan di bidang perkebunan selain karet dan kelapa sawit. Kopi produksi Indonesia dinyatakan memiliki dayasaing di pasar internasional. Hal tersebut dibuktikan salah satunya oleh penelitian Nalurita et al. (2014) yang menemukan bahwa kopi Indonesia memiliki keunggulan komparatif dan kompetitif, dengan dukungan faktor sumberdaya alam, modal, tenaga kerja, IPTEK, industri terkait dan pendukung, peran pemerintah, dan kesempatan. Menurut artikel yang dikutip dari Validnews.co (2017), ada lima negara besar produsen kopi terbesar di dunia yaitu Brazil, Vietnam, Colombia, Indonesia, dan Ethiopia. Pada artikel tersebut juga menjelaskan tentang perbedaan antara kopi yang di produksi Brazil dan Indonesia. Brazil memproduksi kopi dengan jumlah yang besar dan teknologi yang modern, penggunaan teknologi tersebut mendorong produktifitas yang dihasilkan menjadi lebih tinggi. Indonesia juga memiliki speciality coffee antara lain Kopi Gayo, Kopi Mandailing, Kopi Lintong, Kopi Java, dan tentunya kopi luwak yang sudah terkenal hingga kedunia Internasional. Perkembangan tren meminum kopi juga sangat di respon oleh masyarakat Indonesia, terbukti dengan semakin banyaknya coffee shop atau warung kopi yang menawarkan produk mereka, mulai dari yang bernilai puluhan ribu Rupiah hingga ratusan ribu Rupiah. Gambar 1 menjelaskan bagaimana Indonesia merupakan salah satu negara dengan penduduk pengonsumsi kopi terbanyak nomer lima didunia.

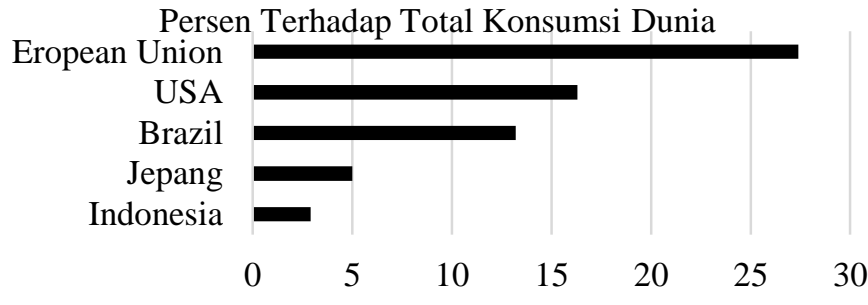

Gambar 1. Lima negara konsumen kopi terbesar dunia Sumber: Validnews.co 2017

Dari Gambar 1 dapat diketahui jika negara pengonsumsi kopi terbanyak didunia adalah Uni Eropa dengan persentase sebesar 27,4, diikuti dengan Amerika Serikat dengan 16,3 persen, Brazil dengan 13,2 persen, Jepang dengan 5 persen, dan terakhir Indonesia dengan 2,9 persen. Konsumsi kopi di Indonesia sendiri selalu mengalami kenaikan dari tahun ke tahun, menurut data yang diambil dari www.databooks.kadata.co.id (2016) menyebutkan bahwa konsumsi kopi di Indonesia dari tahun 2000 hingga 2016 mengalami tren kenaikan. Tabel 1 menyajikan data konsumsi kopi di Indonesia dari tahun 2000 hingga 2016. 
Tabel 1. Konsumsi kopi Indonesia tahun 2000 hingga 2016

\begin{tabular}{cc}
\hline Tahun & Juta bags $(60 \mathrm{~kg})$ \\
\hline 2000 & 1,7 \\
2001 & 2 \\
2002 & 1,8 \\
2003 & 1,8 \\
2004 & 2 \\
2005 & 2,5 \\
2006 & 2,8 \\
2007 & 3,3 \\
2008 & 3,3 \\
2009 & 3,3 \\
2010 & 3,3 \\
2011 & 3,7 \\
2012 & 3,9 \\
2013 & 4,2 \\
2014 & 4,3 \\
2015 & 4,5 \\
2016 & 4,6 \\
\hline
\end{tabular}

Sumber: www.databook.kadata.co.id 2016

Dari Tabel 1 dapat diketahui bahwa tren konsumsi kopi di Indonesia menunjukkan peningkatan, hal itu di buktikan dengan data konsumsi kopi dari tahun 2000 hingga 2016 yang selalu meningkat. Peningkatan terjadi hampir setiap tahun, kecuali pada tahun 2001 dengan 2 juta bags ke tahun 2002 dengan 1,8 juta bags. Peningkatan kembali terjadi dari tahun 2003 hingga 2016. Konsumsi kopi terbanyak ada pada tahun 2016 dengan 4,6 juta bags.

Bogor merupakan kota yang masyarakatnya sangat responsif terhadap perubahan gaya hidup, tak terkecuali budaya meminum kopi masa kini. Dengan memanfaatkan tren konsumsi kopi yang terus meningkat dari tahun ke tahun, masyarakat mulai tertarik dengan mendirikan usaha coffee shop di Kota Bogor Coffee shop seperti Ngopi Doloe, Popolo, Rumah Kopi Ranin, Starbucks, J.Co Donuts \& Coffee, dan The Coffee Bean \& Tea Leaf merupakan contoh contoh kedai kopi yang berdiri di Kota Bogor. Semakin banyaknya usaha coffee shop di Kota Bogor membuktikan bahwa para penikmat kopi di Kota Bogor sangatlah besar. Dari mulai kedai kedai kopi besar seperti Starbucks yang menjual suasana premium dalam meminum kopi hingga kedai kopi yang menyediakan dengan harga yang sangat terjangkau untuk dinikmati. Gambar 2 menunjukan bagaimana pertumbuhan usaha coffee shop di Kota Bogor.

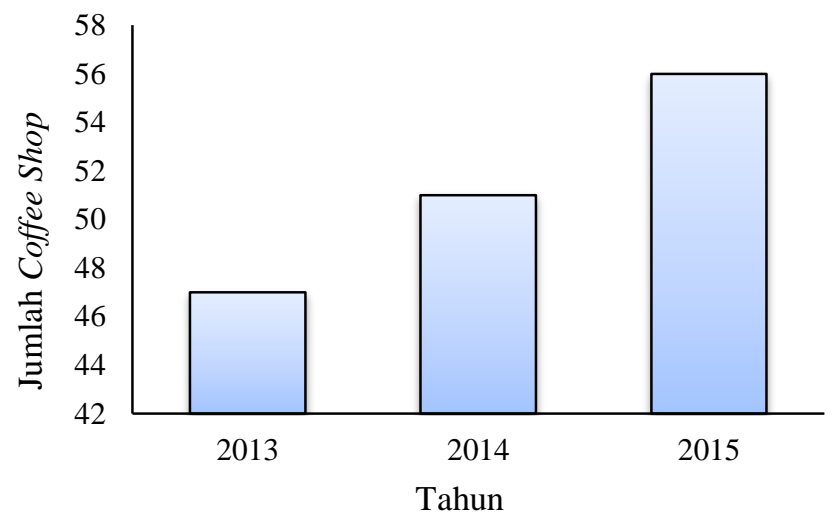

Gambar 2. Pertumbuhan coffee shop di Kota Bogor dari tahun 2013-2015

Sumber: Dinas Pendapatan Daerah Kota Bogor 2015

Gambar 2 menunjukkan bahwa pertumbuhan coffee shop di Kota Bogor mengalami peningkatan dari tahun 2013 hingga tahun 2015. Semakin banyaknya coffee shop di Kota Bogor menjadikan persaingan bisnis di bidang pernyedia minuman kopi menjadi sangat kompetitif

Jurnal Manajemen dan Organisasi (JMO), Vol. 10 No. 2 Agustus 2019, 
dimana setiap produsen atau pemasar harus memiliki keunggulan tersendiri di mata konsumen dibandingkan dengan para pesaing mereka agar menciptakan kepuasan bagi para konsumen. Menurut Kotler dan Keller (2008), kepuasan konsumen merupakan tujuan dan sarana perusahaan, beberapa cara dapat dilakukan demi menjaga kepuasan konsumen salah satunya adalah meningkatkan kualitas, baik kualitas produk maupun kualitas pelayanan, semakin tinggi tingkat kualitas semakin tinggi pula tingkat kepuasan yang dihasilkan. Penentu kepuasan setiap individu tentu berbeda beda, salah satu contohnya adalah tingkat pendapatan atau penghasilan seseorang. Yu dan Fang (2009) mengemukakan bahwa tingkat kepuasan manusia dapat dilihat dari tingkat pendapatannya (mengacu pada hierarki maslow), seseorang yang cenderung berpendapatan rendah akan memilih kualitas produk sebagai faktor utama penentu kepuasannya, namun sesorang yang berpendapatan tinggi akan melihat kualitas pelayanan sebagai faktor utama penentu kepuasannya. Bedasarkan uraian diatas peneliti tertarik untuk melakukan penelitian tentang pengaruh kualitas produk dan kualitas pelayanan ter hadap kepuasan konsumen dan bagaimana pengaruhnya ketika dihadapkan dengan pendapatan atau penghasilan.

\section{METODE PENELITIAN}

Pada penelitian ini peneliti menganalisis pengaruh kualitas produk dan kualitas pelayanan terhadap kepuasan konsumen, dan juga melakukan penelitian tentang seberapa besar pengaruh ketiga variabel tersebut jika dihadapkan dengan pendapatan atau penghasilan seseorang. Data didapat dengan mengumpulkan responden yang mengisi kuesioner baik secara langsung, maupun dengan online melalui situs Google Form. Responden yang dibutuhkan adalah responden yang berdomisili di Kota Bogor serta pernah berkunjung ke coffee shop yang menjadi sampel pada penelitian ini. Dalam menentukan jumlah responden, peneliti menggunakan teknik pemilihan convinience sampling dan quota sampling. Untuk mengukur penelitian, penulis menggunakan skala Likert dengan skor 1 sampai 5 yaitu sangat tidak setuju sampai sangat setuju. Selanjutnya, data yang terkumpul kemudian diuji tingkat validitas dan reliabilitasnya dengan menggunakan program IBM SPSS (Statistical Package Social Science) versi 23. Untuk menguji pengaruh kualitas produk, kualitas pelayanan terhadap kepuasan konsumen peneliti menggunakan metode SEM (Structural Equation Model) dengan software IBM SPSS AMOS versi 20. Kerangka pemikiran dapat dilihat pada Gambar 3. 


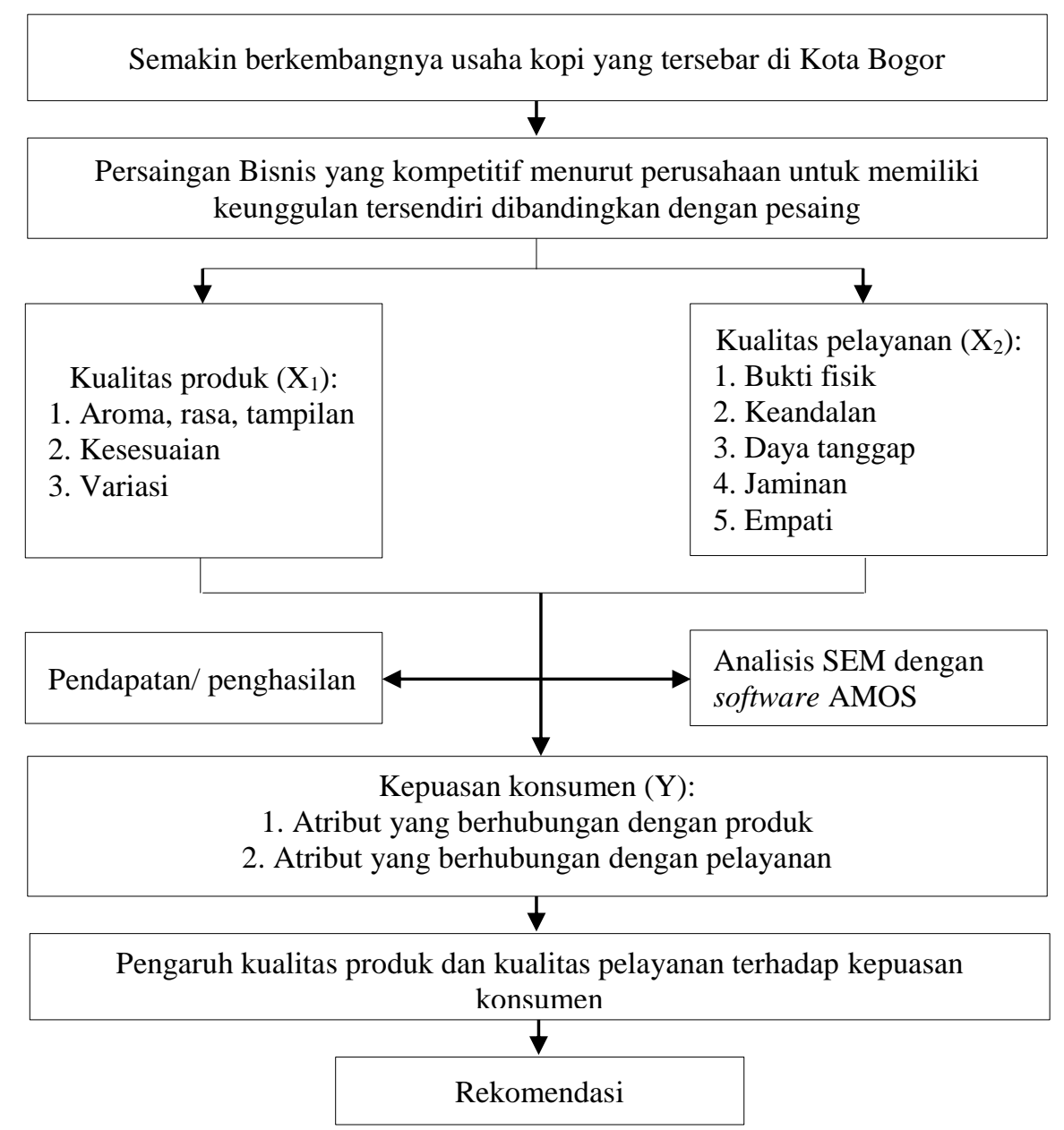

Gambar 3. Kerangka pemikiran

\section{Analisis Structural Equation Modelling (SEM)}

Penelitian ini menggunakan teknik Structural Equation Modeling (SEM) dengan menggunakan software IBM SPSS AMOS versi 20. SEM mempunyai karakteristik yang bersifat sebagai teknik analisis untuk lebih menegaskan (confirm) daripada menerangkan. Maksudnya, seorang peneliti lebih cenderung menggunakan SEM untuk menentukan apakah suatu model tertentu valid atau tidak dari pada menggunakannya untuk menemukan suatu model tertentu cocok atau tidak, meski analisis SEM sering pula mencakup elemen-elemen yang digunakan untuk menerangkan. Untuk mengetahui apakah model yang dibuat didasarkan pada data observasi sesuai dengan model teori atau tidak diperlukan acuan indeks kecocokan model. Berikut ini nilai nilai indeks kecocokan model yang sering digunakan dalam SEM (Sarwono, 2010)

\section{HASIL DAN PEMBAHASAN}

\section{Uji Validitas dan Reliabilitas}

Pengujian ini dilakukan melalui data yang didapat dari 35 responden atau sampel dengan tingkat signifikansi 0,05 maka diperoleh $(\mathrm{R})$ tabel sebesar 0,324. Pengujian ini juga mengukur tingkat reliabilitas dari suatu variabel dengan melihat nilai cronbach's alpha, tingkat nilai kritis dari pengujian ini berada pada nilai 0,6 , yang artinya jika setiap variabel yang diukur menghasilkan angka cronbach's alpha di atas atau sama dengan 0,6 maka variabel tersebut sudah memenuhi tingkat reliabilitas. Hasil uji validitas dan reliabilitas dapat dilihat pada Tabel 2. 
Tabel 2. Hasil uji validitas dan reliabilitas

\begin{tabular}{ccc}
\hline Variabel & Cronbach's Alpha & Correction Item-Total Correlation \\
\hline Kualitas pelayanan & 0,897 & $0,506-0,835$ \\
Kualitas produk & 0,872 & $0,638-0,792$ \\
Kepuasan konsumen & 0,910 & $0,749-0,860$ \\
\hline
\end{tabular}

Pada Tabel 2 dapat dilihat bahwa nilai cronbach's alpha pada variabel kualitas pelayanan mencapai nilai 0,897 , variabel kualitas produk 0,872 , variabel lokasi 0,894 , variabel fasilitas 0,837 , variabel kepuasan konsumen 0,910, dan variabel nilai konsumen 0,934. Nilai crobach's alpha dari seluruh variabel sudah berada di atas nilai kritis. Berdasarkan data yang diperoleh didapatkan hasil nilai Alpha Cronbach yang dihasilkan di atas nilai kritis 0,6. Hal ini menunjukkan bahwa alat pengukur yang digunakan dalam penelitian ini reliabel. Pada Tabel 2 juga dapat dilihat bahwa nilai correction item-total correlation dari seluruh variabel sudah berada di atas 0,324 yang berarti seluruh pertannyaan yang terdapat disetiap variabel sudah valid atau sesuai.

\section{Karakteristik Responden}

Pada karakteristik usia, jumlah responden dengan umur di bawah 20 tahun berjumlah 10,6 persen, usia 21 hingga 30 tahun berjumlah 82,5 persen, usia 31 hingga 40 tahun terdapat 3,8 persen, dan diikuti dengan usia di atas 41 tahun sebanyak 3,2 persen. Pada karakteristik usia didominasi oleh usia antara 21 tahun hingga 30 tahun baik responden berpendapatan kurang dari tiga juta rupiah maupun lebih. Pada karakteristik kedua yaitu jenis kelamin terdapat 165 responden berjenis kelamin laki laki dan 201 reponden berjenis kelamin perempuan. Pada pemisahan responden berdasarkan pendapatan baik diatas tiga juta maupun kurang dari tiga juta didominasi oleh responden dengan jenis kelamin perempuan. Penelitian Sara et al. (2013) mengatakan bahwa perbedaan jenis kelamin juga memengaruhi indikator kepuasan konsumen, pada penelitian tersebut responden laki laki lebih memilih kualitas produk sebagai pemuas kebutuhan mereka, dan responden wanita memilih kualitas pelayanan.

Karakteristik ketiga yaitu pendidikan terakhir, didominasi oleh S1/S2/S3 dengan 46.4 persen. Pada karakteristik ini dapat dilihat bahwa responden berpendapatan kurang dari tiga juta kebanyakan berasal dari kalangan Diploma dan responden dengan pendapatan lebih dari tiga juta berasal dari responden $\mathrm{S} 1 / \mathrm{S} 2 / \mathrm{S} 3$. Karakteristik selanjutnya yaitu perekerjaan, terdapat enam jenis pekerjaan yang menjadi pertanyaan kuisioner yaitu pelajar atau mahasiswa, wiraswasta, professional, pegawai pemerintah, ibu rumah tangga, dan lainya. Distribusi responden terbanyak pada kategori pekerjaan terdapat pada pelajar atau mahasiswa sebesar 39,6 persen dan tingkat pendapatan kurang dari tiga juta juga didominasi oleh pelajar atau mahasiswa sebesar 120 responden. Kategori pekerjaan yang mendominasi dari responden berpenghasilan lebih dari tiga juta adalah profesional sebanyak 76 reponden.

Karateristik berikutnya yaitu pengeluaran rata rata sekali kunjungan ke coffee shop, pada karakteristik ini terdapat empat indikator dengan distribusi responden terbesar pada Rp 50.000,00

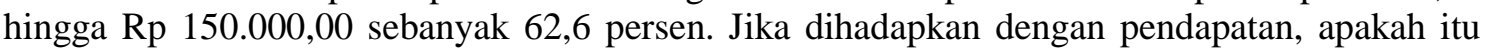
lebih dari tiga juta ataupun kurang juga didominasi dengan responden yang memilih pengeluaran rata rata sekali berkunjung Rp 50.000,00 hingga Rp 150.000,00 dengan sebaran responden yaitu 80 responden dengan pendapatan kurang dari tiga juta dan 149 responden dengan pendapatan lebih dari tiga juta.

Pada karakteristik frekuensi kedatangan ke coffee shop terdapat empat indikator dengan distribusi responden terbesar terdapat pada kurang dari dua kali seminggu sebanyak 64,2 persen, juga pada karakteristik ini kebanyakan responden, baik berpendapatan kurang dari tiga juta ataupun lebih, memilih kurang dari dua kali seminggu sebagai indikator pada karakteristik frekuensi kedatangan. Karateristik selanjutnya yaitu alasan utama berkunjung ke coffee shop dengan enam indikator, dan distribusi paling banyak pada alasan utama berkunjung ke coffee shop ada pada hang out atau relax dengan tingkat presentase sebesar 40,2, karakteristik ini menempatkan indikator hang out atau relax sebagai alasan utama bagi mereka yang berpendapatan lebih dari tiga juta maupun kurang dari tiga juta. Pada kategori faktor utama 
mengunjungi coffee shop terdapat tujuh indikator dengan distribusi paling banyak ada pada atmosfer café yang nyaman sebanyak 30,9 persen, karakteristik ini juga menempatkan responden berpenghasilan lebih dari tiga juta ataupun kurang dari dari tiga juta pada indikator atmosfer café sebagai indikator utama pada karakteristik alasan utama mengunjungi.

Kategori pilihan jenis coffee shop yang paling disukai terdapat dua pilihan yaitu coffee shop lokal dan internasional, distribusi pada pilihan jenis coffee shop ini cukup merata walaupun coffee shop internasional lebih banyak, dengan jumlah responden sebanyak 212 reponden dan coffee shop lokal sebanyak 154 responden. Pada karakteristik ini terdapat temuan yang unik bahwa respoden yang memiliki pendapatan kurang dari tiga juta kebanyakan memilih coffee shop internasional, mengingat bahwa harga kopi pada coffee shop internasional lebih mahal jika dibandingkan dengan coffee shop lokal. Penelitian Remiasa dan Lukman (2008) mengemukakan bahwa ada faktor yang memengaruhi penikmat kopi lebih memilih coffee shop asing atau Internasional dibandingkan dengan coffee shop lokal yaitu pada kualitas pelayanan, dimana coffee shop internasional memiliki kualitas pelayanan lebih bagus dibandingkan coffee shop lokal. Namun pada penelitian Bouw dan Knipping (2015) mengemukakan bahwa tidak ada perbedaan antara orang yang berpendapatan rendah, menengah, maupun tinggi dalam pemilihan coffee shop.

Pada karakteristik coffee shop yang paling sering dikunjungi terdapat enam coffee shop yaitu, Starbucks Coffee, The Coffee Bean \& Tea Leaf, JCo Donuts \& Coffee, Popolo Coffee, Ngopi Doeloe, Rumah Kopi Ranin. Distribusi responden terbanyak pada karateristik coffee shop yang paling sering dikunjungi yaitu Starbucks Coffee dengan presentase sebesar 40,4 persen, sama seperti karakteristik pemilihan coffee shop, responden dengan pendapatan kurang dari tiga juta lebih memilih Starbucks Coffee sebagai coffee shop yang paling sering dikunjungi. Karateristik terakhir yaitu berapa kali kunjungan ke coffee shop yang dipilih terdapat empat indikator dengan distribusi terbesar ada pada indikator lebih dari 10 kali dengan jumlah responden sebanyak 46,2 persen, indikator ini juga didominasi oleh responden dengan pendapatan lebih dari tiga juta maupun kurang dari tiga juta.

\section{Analisis Structural Equation Model (SEM) Pertama}

Pada penelitian ini menggunakan tiga variabel. Masing masing indikator pada model ini menggunakan indikator awal dari setiap variabel yaitu kualitas produk, kualitas pelayanan, dan kepuasan konsumen. Pada model ini juga menghilangkan indikator yang memiliki nilai muatan faktor kurang dari 0,6. Model SEM dari penelitian ini dapat dilihat pada Gambar 4.

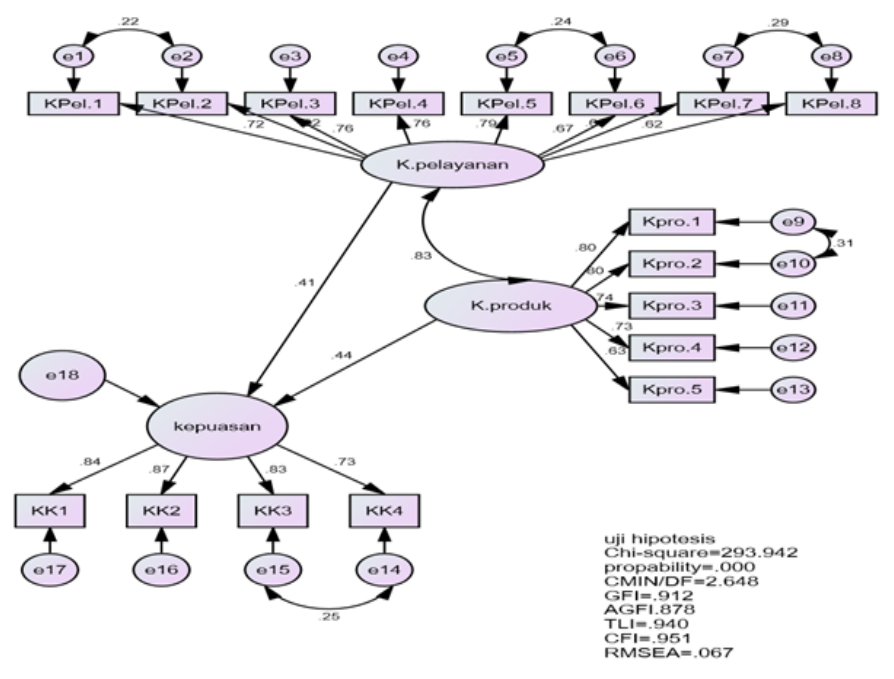

Gambar 4. Model penelitian pertama

Pada Gambar 4 dapat dilihat bahwa setiap variabel memiliki nilai muatan faktor yang lebih dari 0,6. Proses selanjutnya juga dilakukan uji kesesuaian atau goodness of fit pada model ini untuk dilihat seberapa baguskah model yang dibuat pada penelitian ini.

Jurnal Manajemen dan Organisasi Vol. 10 No. 2 Agustus 2019 Agustus 2019, 
Tabel 3. Hasil uji goodness of fit model

\begin{tabular}{lcll}
\hline Kriteria & Cut-off value (nilai kritis) & Hasil & Keterangan \\
\hline Chisquare & Diharapkan kecil & 293,942 & Good fit \\
\hline $\begin{array}{l}\text { RMSEA (root mean square error of } \\
\text { approximation) }\end{array}$ & $\leq 0,08$ & 0,067 & Good fit \\
\hline GFI (goodness of fit) & $\geq 0,90$ & 0,912 & Good fit \\
\hline $\begin{array}{l}\text { CMIN/DF (the minimum sample } \\
\begin{array}{l}\text { Discrepancy function/degree of } \\
\text { freedom) }\end{array}\end{array}$ & $\leq 5$ & 2,648 & Good fit \\
\hline CFI (comparative fit index) & $\geq 0,90$ & 0,951 & Good fit \\
\hline
\end{tabular}

Tabel 4. Hasil uji kausalitas model penalitian

\begin{tabular}{lllllll}
\hline Endogen & & Eksogen & Estimate & C.R. & P & Keterangan \\
\hline Kepuasan & $<--$ & Kualitas produk & 0,396 & 4,517 & $* * *$ & Berpengaruh signifikan \\
\hline Kepuasan & $<--$ & Kualitas pelayanan & 0,451 & 4,248 & $* * *$ & Berpengaruh signifikan \\
\hline
\end{tabular}

Dari Tabel 3 dapat dilihat nilai dari masing masing kriteria yang digunakan dalam penelitian ini, yaitu Chisquare yang bernilai 293,942, kriteria RMSEA (Root Mean Square Error of Approximation) bernilai 0,067, kriteria GFI (Goodness Of Fit) bernilai 0,912, kriteria CMIN/DF (The Minimum Sample Discrepancy Function/Degree of Freedom) bernilai 2,648, dan kriteria CFI (Comparative Fit Index) bernilai 0,951. Semua kriteria bernilai diatas nilai kritis. Dari Tabel 4 dapat diketahui bahwa kualitas produk dan kualitas pelayanan sama sama memiliki pengaruh yang signifikan terhadap kepuasan konsumen pada responden secara keseluruhan.

\section{Analisis Structural Equation Model (SEM) Kedua}

Kota Bogor merupakan salah satu Kota besar yang terletak di Provinsi Jawa Barat, Indonesia. Dampak dari era globalisasi juga dirasakan oleh masyarakat Kota Bogor, hal ini dikarenakan jarak yang dekat antara Kota Bogor dan Ibu Kota Indonesia yaitu Kota Jakarta, pendeknya jarak antara kedua kota tersebur membuat setiap budaya budaya modern yang ada di Ibu Kota menyebar luas hingga Kota Bogor, termasuk salah satunya budaya meminum kopi. Banyaknya usaha kedai kopi asing ataupun lokal seperti Starbuck's dan kedai kedai lokal lain di Ibu Kota memberikan pengaruh bagi warga Kota Bogor secara tidak langsung. Dampak dari persebaran budaya yang cepat menyebabkan masayarakat Kota Bogor harus siap dalam menghadapi era modern seperti sekarang ini. Kota Bogor sendiri merupakan Kota dengan Upah Minimum Kabupaten atau Kota (UMK) terbesar nomer lima di Provinsi Jawa Barat. Dasar hukum dari pemberlakuan UMK di Jawa Barat tahun 2018 yakni keptusan Gubernur Jawa Barat Nomor 561/kep.1065-yangbangsos/2017 tentang UMK di Daerah Provinsi Jawa Barat Tahun 2018 tanggal 21 November tahun 2017. Diketahui bahwa UMK paling besar di Provinsi Jawa Barat terletak di Kabupaten Karawang dengan Rp 3.919.291,00, nomer dua yaitu Kota Bekasi dengan Rp 3.915.354,00, nomer tiga yaitu Kabupaten Bekasi sebesar Rp 3.837.940,00, nomer empat yaitu Kota Depok sebesar Rp 3.584.700, dan yang terakhir yakni Kota Bogor sebesar Rp 3.557.147,00. Tingginya tingkat UMK Kota Bogor dipengaruhi oleh biaya hidup di Kota Bogor. Tingginya UMK juga menyebabkan peningkatan konsumsi dari setiap masyarakat atau individu di Kota Bogor. Dari uraian tersebut maka peneliti tertarik untuk melakukan penelitian lebih lanjut yaitu mengenai pengaruh kualitas produk dan kualitas pelayanan terhadap kepuasan konsumen jika dihadapkan dengan pendapatan seseorang atau individu masyarakat di Kota Bogor. Penelitian ini menguji lagi dan menganalisis data yang telah dibagi berdasarkan penghasilan yaitu antara responden yang berpendapatan di bawah tiga juta dan responden dengan pendapatan di atas tiga juta. Jumlah responden yang memiliki pendapatan di bawah tiga juta sebesar 42,3 persen dan yang memiliki pendapatan lebih dari tiga juta sebesar 57,7 persen.

\section{Responden Dengan Penghasilan Di bawah Tiga Juta}

Reponden dengan pendapatan di bawah tiga juta berjumlah sebesar 42,3 persen dari keseluruhan responden yang mengisi kuisioner. Permodelan ini ditujukan untuk mengetahui apakah meraka akan lebih memilih produk sebagai faktor utama atau pelayanan. Gambar 5 
menunjukkan permodelan SEM jika menggunakan responden dengan pendapatan di bawah tiga juta.

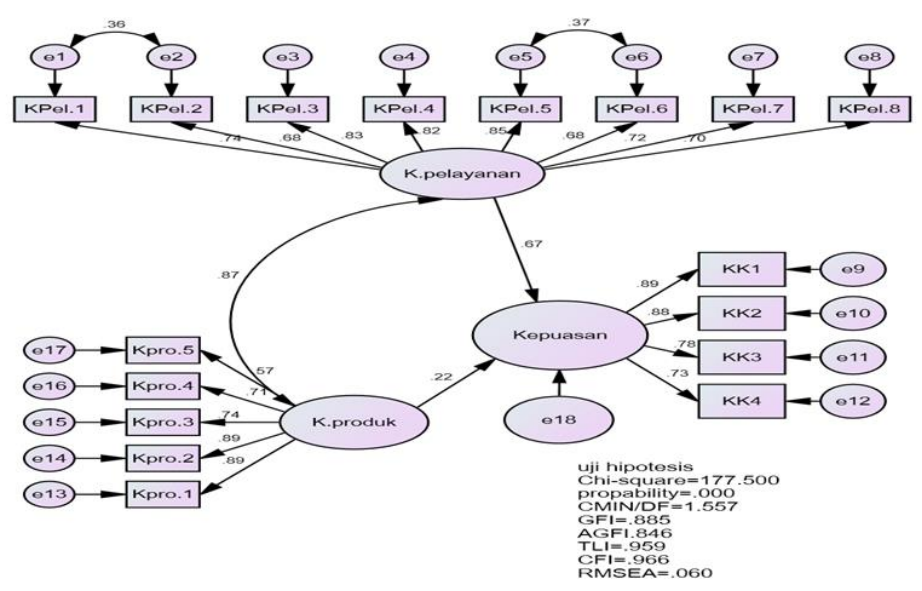

Gambar 5. Model SEM responden berpenghasilan di bawah tiga juta

Selanjutnya dilakukan uji kecocokan model untuk mengevaluasi derajat kesesuaian antara data dengan model. Hasil analisis goodness of fit dapat dilihat pada Tabel 5.

Tabel 5. Hasil uji goodness of fit responden penghasilan di bawah tiga juta

\begin{tabular}{lccl}
\hline Kriteria & Cut-off value (nilai kritis) & Hasil & Keterangan \\
\hline Chisquare & Diharapkan kecil & 177,500 & Good fit \\
\hline $\begin{array}{l}\text { RMSEA (root mean square error of } \\
\text { approximation) }\end{array}$ & $\leq 0,08$ & 0,060 & Good fit \\
\hline GFI (goodness of fit) & $\geq 0,90$ & 0,885 & Fit \\
\hline $\begin{array}{l}\text { CMIN/DF (the minimum sample } \\
\begin{array}{l}\text { Discrepancy function/degree of } \\
\text { freedom) }\end{array}\end{array}$ & $\leq 5$ & 1,557 & Good fit \\
\hline CFI (comparative fit index) & $\geq 0,90$ & 0,966 & Good fit \\
\hline
\end{tabular}

Dari Tabel 5 dapat dilihat nilai dari masing masing kriteria yang digunakan dalam penelitian ini. Kriteria pertama yaitu Chisquare yang bernilai 177,500, kriteria RMSEA (Root Mean Square Error of Approximation) bernilai 0,060, kriteria GFI (Goodness Of Fit) bernilai 0,885, kriteria CMIN/DF (The Minimum Sample Discrepancy Function/Degree of Freedom) bernilai 1,557, dan kriteria CFI (Comparative Fit Index) bernilai 0,966. Hasil dari goodness of fit pada model sudah memenuhi semua kriteria kecuali GFI dengan nilai kritis $\geq 0.90$ namun menghasilkan nilai sebesar 0,885 . Selanjutnya nilai hasil uji kausalitas pengaruh variabel endogen dan eksogen dapat dilihat pada Tabel 6.

Tabel 6. Hasil uji kausalitas responden penghasilan di bawah tiga juta

\begin{tabular}{|c|c|c|c|c|c|c|}
\hline Endogen & & Eksogen & Estimate & C.R. & $\mathrm{P}$ & Keterangan \\
\hline Kepuasan & $-->$ & $\begin{array}{l}\text { Kualitas } \\
\text { produk }\end{array}$ & 0,191 & 1,598 & 110 & $\begin{array}{l}\text { Tidak berpengaruh } \\
\text { signifikan }\end{array}$ \\
\hline Kepuasan & $-->$ & $\begin{array}{l}\text { Kualitas } \\
\text { pelayanan }\end{array}$ & 0,715 & 4,580 & $* * *$ & $\begin{array}{l}\text { Berpengaruh } \\
\text { signifikan }\end{array}$ \\
\hline
\end{tabular}

Hasil analsisis dari model SEM responden pendapatan di bawah tiga juta pada Tabel 6 menunjukan ada perbedaan antara pengaruh kualitas produk dan kualitas pelayanan. Responden dengan pendaptan kurang dari tiga juta justru memilih kualitas pelayanan sebagai faktor yang dominan untuk memuaskan mereka saat berada di coffee shop. 


\section{Responden Dengan Penghasilan Di atas Tiga Juta}

Reponden berpendapatan lebih dari tiga juta sebesar 57,7 persen dari keseluruhan responden yang mengisi kuisioner. Untuk responden dengan pendapatan di atas tiga juta terdiri dari empat golongan yaitu pendapatan Rp3.000.000,00 - Rp 5.000.000,00, Rp 5.000.000,00 - Rp 7.000.000,00, Rp 7.000.000,00 - Rp 10.000.000,00, dan > Rp 10.000.000,00. Gambar 7 menunjukan permodelan SEM jika menggukan reponden dengan pendaptan di atas tiga juta Terdapat tiga variabel yang diuji pada tahap pengujian dengan menggunakan responden berpendapatan di atas tiga juta, setiap variabel memiliki indikatornya masing masing. Gambar 7 menunjukan permodelan penelitian dengan meggunakan responden berpendapatan di atas tiga juta rupiah. Dapat dilihat pada Gambar 7 indikator dari kualitas pelayanan ada dua indikator yang dihilangkan dikarenakan nilai indikator tersebut memiliki nilai muatan faktor kurang dari 0,6, Lalu selanjutnya dilakukan uji kecocokan model untuk mengevaluasi derajat kesesuaian antara data dengan model. Hasil uji goodness of fit dari model SEM dengan responden berpendapatan di atas tiga juta dapat dilihat pada Tabel 6.

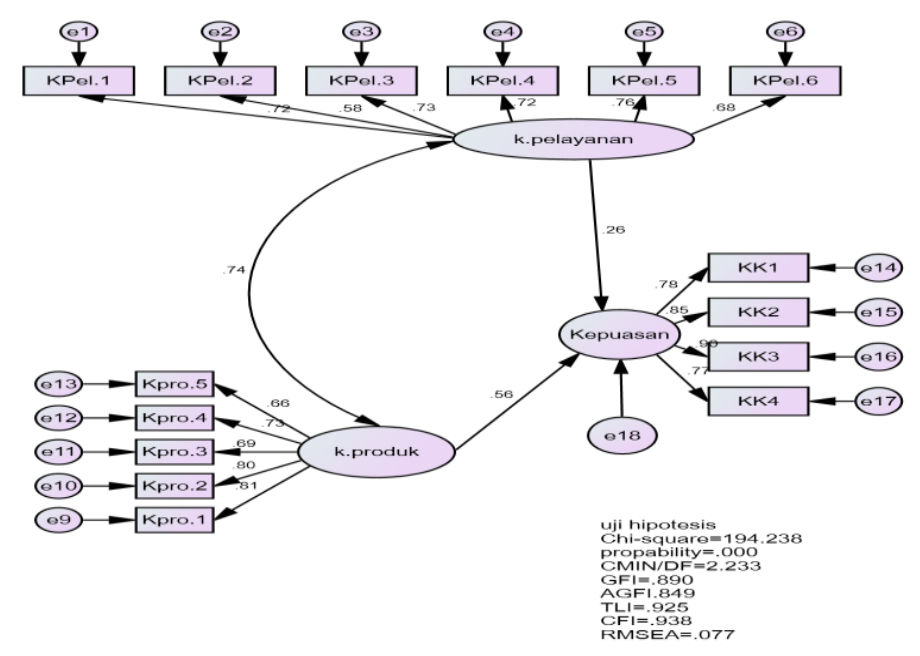

Gambar 6. Model SEM responden berpenghasilan di atas tiga juta

Tabel 7. Hasil uji goodness of fit responden penghasilan di atas tiga juta

\begin{tabular}{llll}
\hline Kriteria & Cut-off value (nilai kritis) & Hasil & Keterangan \\
\hline Chisquare & Diharapkan kecil & 194,238 & Good fit \\
\hline $\begin{array}{l}\text { RMSEA (root mean square error of } \\
\text { approximation) }\end{array}$ & $\leq 0,08$ & 0,077 & Good fit \\
\hline GFI (goodness of fit) & $\geq 0,90$ & 0,890 & Fit \\
\hline $\begin{array}{l}\text { CMIN/DF (the minimum sample } \\
\begin{array}{l}\text { Discrepancy function/degree of } \\
\text { freedom) }\end{array}\end{array}$ & $\leq 5$ & 2,223 & Good fit \\
\hline CFI (comparative fit index) & $\geq 0,90$ & 0,938 & Good fit \\
\hline
\end{tabular}

Dari Tabel 7 dapat dilihat nilai dari masing masing kriteria yang digunakan dalam penelitian ini. Kriteria pertama yaitu Chisquare yang bernilai 194,238, kriteria RMSEA (Root Mean Square Error of Approximation) bernilai 0,077, kriteria GFI (Goodness Of Fit) bernilai 0,890, kriteria CMIN/DF (The Minimum Sample Discrepancy Function/Degree of Freedom) bernilai 2,223, dan kriteria CFI (Comparative Fit Index) bernilai 0,938. Hasil dari goodness of fit pada model sudah bagus namun belum seluruhnya berada di atas nilai kritis. Terlihat pada GFI Jurnal Manajemen dan Organisas Vol. 10 No. 2 , Agustus 2019, hasilnya tidak memenuhi nilai kritis yang diinginkan meskipun sangat mendekati. Selanjutnya dilakukan uji kausalitas, nilai hasil uji kausalitas dapat dilihat pada Tabel 8. 
Tabel 8. Hasil uji kausalitas responden penghasilan di atas tiga juta

\begin{tabular}{ccccccc}
\hline Endogen & & Eksogen & Estimate & C.R. & P & Keterangan \\
\hline Kepuasan & $<---$ & Kualitas produk &, 324 & 5,381 & $* * *$ & Berpengaruh signifikan \\
\hline Kepuasan & $<---$ & Kualitas pelayanan &, 513 & 2,646 &, 008 & Berpengaruh signifikan \\
\hline
\end{tabular}

Hasil analsisis dari model SEM dengan menggunakan responden berpendapatan lebih dari tiga juta yang dapat dilihat pada Tabel 8 menunjukkan variabel kualitas produk dan kualitas pelayanan sama sama berpengaruh signifikan terhadap kepuasan konsumen. Dapat dikatakan bahwa semua hipotesis awal penelitian sesuai dengan hasil penelitian, kecuali pada pengaruh kualitas produk pada responden dengan pendapatan kurang dari tiga juta rupiah. Penelitian ini mengemukakan hasil yang sama dengan penelitian Aryani dan Rosinta (2010) bahwa kualitas pelayanan berpengaruh signifikan terhadap kepuasan konsumen, juga pada penelitian Sofyan et al. (2013) mengemukakan bahwa kualitas pelayanan berpengaruh positif dan signifikan terhadap kepuasan konsumen. Mulyono et al. (2007) mengemukakan bahwa semakin tinggi kualitas produk semakin tinggi pula kepuasan konsumen, begitupun dengan kualitas pelayanan, hasil dari penelitian tersebut mengemukakan hasil yang sama dengan penelitian ini. Basrah dan Arifin (2012) juga mengemukakan bahwa kualitas produk dan kualitas pelayanan berpengaruh secara signifikan terhadap kepuasan konsumen.

Pada penelitian ini terdapat satu temuan yang tidak biasa yaitu konsumen dengan pendapatan kurang dari tiga juta rupiah memilih kualitas pelayanan sebagai faktor dominan pemuas kebutuhan mereka dibandingkan dengan kualitas produk. Hal ini tentu tidak sejalan dengan asumsi Maslow's yang mengacu pada penelitian Yu dan Fang (2009) bahwa seseorang yang memiliki pendapatan yang cenderung rendah akan memilih kualitas produk sebagai pemuas kebutuhannya. Namun pada penelitian ini tidak terbukti adanya perbedaan antara responden dengan pendapatan rendah maupun tinggi, individu dengan pendapatan yang tergolong rendah yaitu di bawah tiga juga menunjukkan bahwa kualitas produk tidak memiliki pengaruh yang signifikan terhadap kepuasan konsumen pada penelitian ini. Akan tetapi menunjukkan sebaliknya bahwa individu dengan pendapatan rendah lebih memilih kualitas pelayanan sebagi indikator yang kuat untuk pemuas kebutuhan mereka. Kasnaeny et al. (2013) juga mengemukakan bahwa tidak selamanya konsumen berkunjung ke coffee shop termotivasi untuk merasakan produk kopi disana, namun ada faktor faktor lain yang memengaruhinya.

Moon dan Quelch (2015) berpendapat bahwa konsumen coffee shop asing telah berkembang, terdapat beberapa konsumen baru dari mulai umur yang lebih muda, tingkat pendidikan yang rendah, dan memiliki pendapatan yang lebih rendah dibandingkan dengan orang yang berkunjung ke coffee shop, mereka memiliki presepsi yang berbeda beda saat berkunjung ke coffee shop. Dalam penelititan Kasnaeny et al. (2013) yang berjudul Hedonic and Utilitarian Motives of Coffee Shop Customer in Makassar, di Indonesia terdapat berbagai motif seseorang dalam memilih coffee shop salah satunya adalah keinginan untuk merasakan perbedaan coffee shop satu dengan yang lainnya. Dengan adanya perbedaan coffee shop satu dengan yang lain, maka para pengusaha perlu strategi dalam menjalankan bisnis agar tidak kalah bersaing, salah satunya adalah dengan meningkatkan kualitas. Para pengusaha coffee shop di Kota Bogor perlu meningkatkan atau mempertahankan kualitas demi tercapainya kepuasan konsumen. Jahanshani et al. (2011) berpendapat kualitas produk dan kualitas pelayanan sangat penting bagi perusahaan untuk mencapai kepuasan konsumen.

Penelitian Ko dan Chiu (2008) mengungkapkan bahwa tingkat kenyamanan yang tinggi mengurangi sensitifitas harga pelanggan (customer price sensitivity) Para manajer harus fokus dalam meningkatkan kualitas produk dan kualitas pelayanan (Alex \& Thomas, 2011). Chen dan $\mathrm{Hu}$ (2009) berpendapat pentingnya mengidentifikasi atribut kualitas yang paling bernilai di mata pelanggan, hal ini dapat membantu perusahaan dalam mengembangkan strategi bersaing dan membedakan diri dari pesaing. 


\section{Implikasi Manajerial}

Untuk memenangkan persaingan dalam dunia bisnis coffee shop diperlukan strategi yang jitu, salah satunya adalah dengan meningkatkan kepuasan konsumen. Maieiam (2009) berpendapat informasi dan data dapat membantu untuk membuat keputusan atau memahami harapan pelanggan dan mencari tahu kepuasan konsumen bagi para pengembang bisnis coffee shop dan juga memberi pedoman bagi pendatang baru yang ingin membuka bisnis baru sebagai pemilik coffee shop atau kedai kopi.

Hasil dari pengujian dan permodelan yang telah dilakukan menunjukan bagaimana pentingnya meningkatkan kualitas baik kualitas produk sebagai core product ataupun kualitas layanan sebagai nilai jual tambah. Jika ingin tetap bertahan pada industri penyedia kopi sehendaknya para produsen dan pemasar memperhatikan apa yang menjadi faktor penentu kepuasan konsumen. Implikasi manajerial ini menggunakan konsep dasar dari Terry (2003) yaitu Planning, Organizing, Actuating, dan Controlling:

\section{Planning}

Kegiatan perencaan termasuk salah satu tindakan penting untuk mengatasi masalah yang akan terjadi dimasa yang akan datang. David (2011) berpendapat bahwa teknik perencanaan produk dan pelayanan yang paling efektif adalah dengan melakukan uji pemasaran (test marketing). Bagi perusahaan atau pendatang baru bisnis coffee shop dapat melakukan uji pemasaran dahulu sebelum memasarkan produk produk baru, inovasi baru, dan bisnis baru. Dalam penelitian Hung (2012) mengemukakan bahwa perusahaan perlu memperkenalkan produk baru satu kali dalam satu periode tertentu, produk baru juga dianggap salah satu faktor kunci dalam manajemen coffee shop. Pada penelitian Jan et al. (2013) mengemukakan bahwa sebagian kelompok konsumen coffee shop tertarik dengan produk kopi dengan elemen baru. Dalam Lampiran 2 juga menunjukan bahwa aroma dan rasa merupakan elemen penting dari suatu produk kopi pada responden yang berpenghasilan dibawah tiga juta, sehingga perlu adanya kegiatan merencanakan produk kopi baru yang berfokus pada aroma dan rasa.

2. Organizing

Pelayan biasanya berhubungan langsung dengan konsumen sebagai lini pertama dalam perusahaan. Starbuck's CEO dan Chairman Howard Schultz percaya bahwa rahasia untuk sukses bukan berada di kopinya melainkan pada oranganya (Hung, 2012). Dapat dilihat pada Lampiran 1 bahwa tingkat kepuasan konsumen juga dipengaruhi dengan tingkat pelayanan pada coffee shop tersebut, untuk itu pentingnya upaya dalam meningkatkan kinerja karyawan harus sangat diperhatikan oleh perusahaan, contohnya dengan pelatihan karyawan dalam kurun satu periode tertentu. Perusahaan juga dapat memberikan penjelasan yang lebih rinci tentang job desk dari masing masing bagian dan siapa yang bertanggung jawab atas pekerjaanya.

3. Actuating

Keberlangsung perusahaan merupakan tanggung jawab setiap elemen yang ada didalamnya, mulai dari karyawan hingga ke direktur. Dalam mencapai kepuasan konsumen semuanya harus bekerja keras untuk memenuhi kebutuhan konsumen atau bahkan malampauinya, untuk itu perlu adanya komunikasi yang baik secara vertikal maupun horizontal. Pemimpin yang baik adalah pemimpin yang memiliki hubungan baik dengan karyawanya guna memotivasi mereka tentang visi dan misi perusahaan yang harus dicapai. Perusahaan juga dapat memberi penghargaan bagi karyawannya yang berkerja sangat baik dan memberi hukuman bagi karyawannya yang melanggar

\section{Controlling}

Pengendalian atau controlling merupkan segala aktivitas yang dilakukan untuk memastikan bahwa operasi aktual sejalan dengan operasi yang direncanakan (David, 2011). Controlling dapat dilakukan dengan mengevaluasi kinerja karyawan maupun atasan setiap 


\section{KESIMPULAN}

Penelitian ini dilakukan untuk mengetahui pengaruh kualitas produk dan kualitas pelayanan terhadap kepuasan konsumen pada coffee shop di Kota Bogor, dan juga mengetahui pengaruh kedua kualitas tersebut jika dihadapkan dengan pendapatan atau penghasilan. Hasil dari penelitian ini mengemukakan bahwa:

1. Kualitas produk berpengaruh signifikan terhadap kepuasan konsumen pada seluruh responden.

2. Kualitas pelayanan berpengaruh signifikan terhadap kepuasan konsumen pada seluruh respoden.

3. Kualitas produk tidak berpengaruh signifikan terhadap kepuasan konsumen pada responden berpendapatan di bawah tiga juta. Berbeda dengan variabel kualitas pelayanan yang berpengaruh signifikan

4. Kualitas poroduk dan kualitas pelayanan berpengaruh signifikan terhadap kepuasan konsumen pada responden berpendapatan di atas tiga juta.

Kualitas produk dan kualitas pelayanan adalah hal penting yang harus diperhatikan oleh para pengusaha coffee shop di Kota Bogor. Dengan konsumen yang puas dapat memberikan dampak yang positif bagi perusahaan contohnya, memberikan keuntungan, memperoleh loyalitas pelanggan, media promosi yang efektif, dll. Keterbatasan pada penelitian ini yaitu menggunakan dua variabel terikat dan satu variabel bebas, pada penelitian lanjut dapat dilakukan dengan variabel lain yang berhubungan dengan kepuasan konsumen. Perbandingan hasil pada penelitian ini dilakukan dengan penelitian lain yang sejenis, namun terdapat beberapa perbedaan seperti, berbeda tempat penelitian, metode penelitian. Untuk penelitian lebih lanjut dapat dilakukan dengan membandingkan hasil dengan penelitian lain yang memiliki kesamaan tempat, metode, dan objek penelitian. Pada penelitian selanjutnya juga dapat dilakukan dengan menganalisis kualitas produk dan kualitas pelayanan terhadap kepuasan konsumen yang dihadapkan dengan pendidikan, jenis kelamin, pekerjaan, tempat tinggal, dll.

\section{DAFTAR PUSTAKA}

Alex, D., \& Thomas, S. (2011). Impact of Product Quality, Service Quality and Contextual Experience on Customer Perceived Value and Future Buying Intentions. European Journal of Business and Management [internet]. [diunduh 2018 Jul 3]. Tersedia pada :https://dyuthi.cusat.ac.in/xmlui/bitstream/handle/purl/4657/Impact\%20of\%20Product $\% 2$ 0Quality\%2C\%20Service\%20Quality\%20and\%20ContextualExperience\%20on\%20Custo mer\%20Perceived $\% 20$ Value $\% 20$ and $\% 20$ Future $\% 20$ Buying $\% 20$ intentions.pdf?sequence $=$ 1 .

Aryani, D., \& Rosinta, F. (2010). Pengaruh Kualitas Layanan Terhadap Kepuasan Pelanggan Dalam Membentuk Loyalitas Pelanggan. Jurnal Ilmu Administrasi dan Organisasi [Internet]. [diunduh 2018 Mar 5]; 17: 114-126. Diakses pada: http://www.ijil.ui.ac.id/index.php/jbb/article/download/632/617.

Bouw, E., \& Knipping, A. (2015). Coffee Shops and Gentrification A study on Pilsen, Chicago and Parkdale, Toronto. University of Groningen [internet]. [diunduh 2018 Okt 3]. Diakses pada:

https://www.researchgate.net/publication/286342312_Coffee_Shops_and_Gentrification_ -_A_study_on_Pilsen_Chicago_and_Parkdale_Toronto.

Chen, P. T., \& Hu, H. H. (2009). How determinant attributes of service quality influence customer-perceived value an empirical investigation of the Australian coffee outlet industry. Journal of Management Development [internet]. [diunduh 2018 Jul 3]. Diakses pada: https://www.emeraldinsight.com/doi/abs/10.1108/09596111011042730.

Databooks Katadata. (2016). Beberapa konsumsi kopi di Indonesia [Internet]. [diunduh 2018 Maret 18]. Tersedia pada: https://databoks.katadata.co.id/datapublish/2017/07/03/berapakonsumsi kopi-indonesia.

David, F. R. (2011). Manajemen Strategis. Jakarta: Salemba Empat.

Jurnal Manajemen dan Organisasi

(JMO),

Vol. 10 No. 2 Agustus 2019, 
Dinas Pendapatan Daerah Kota Bogor. (2015). Pertumbuhan Coffee Shop di Kota Bogor tahun 2013-2015.

Hung, L. (2012). A Study of Consuming Behaviors of Budget Coffee. Business and Management Research [internet]. [diunduh 2018 Nov 2]. Diakses pada: http://dx.doi.org/10.5430/bmr.v1n1p48.

Infodepok. (2018). Daftar UMK Jawa Barat Tahun 2018 [Intenet]. [diunduh 2018 Jul 14]. Tersedia pada: http://infodepok.net/daftar-umk-jabar-2018-karawang-tertinggipangandaran-terendah-depok-keempat-detail-57043.html.

Jahanshani et al. (2011). Study The Effect of Customer Service and Product Quality on Customer Satisfaction and Loyalty. International Journal of Humanities and Social Science [Internet]. [diunduh 2018 Mar 30]. Diakses pada:

https://www.researchgate.net/profile/Seyed_Mohammad_Sadegh_Khaksar/publication/23 5791092_Study_of_the_effects_of_customer_service_and_product_quality_on_customer_ satisfaction_and_loyalty/links/57a096fb08ae94fico454eb4c9d.pdf.

Jan, C. J, Long, L. T, \& Stanley, H. (2013). A study on the lifestyles of coffee consumers in Taiwan [internet]. [diunduh 2018 Nov 2]. Diakses pada: http://design-cu.jp/iasdr2013/papers/12842b.pdf.

Kasnaeny, K., Sudiro, A., Hadiwidjojo, D., \& Rohman, F. (2013). Patronage Buying Motives of Coffee shop's Consumers. Journal of Business and Management [internet]. [diunduh 2018 Nov 14]. Tersedia pada:

http://www.iosrjournals.org/iosr-jbm/papers/Vol8-issue3/D0831922.pdf.

Kasnaeny, K., Sudiro, A., Hadiwidjojo, D., \& Rohman, F. (2013). Hedonic and Utilitarian Motives of Coffee Shop Customer in Makassar, Indonesia. European Journal of Business and Management [internet]. [diunduh 2018 Nov 14]. Tersedia pada: https://www.iiste.org/Journals/index.php/EJBM/article/view/8043.

Ko, W. H., \& Chiu, P. C. (2008). The Relationships Between Brand Attitude, Customers' Satisfaction and Revisiting Intentions of the University Students-A Case Study of Coffee Chain Stores in Taiwan. Journal of Foodservice Business Research [internet]. [diunduh 2018 Jul 20]. Diakses pada: https://www.tandfonline.com/doi/abs/10.1080/15378020801926791.

Kotler, P., \& Keller, K. L. (2008). Manajemen Pemasaran. Jakarta: Erlangga.

Maieiam, S. (2009). Evaluating Customer Satisfaction Towards The Coffee Shop Third Place. [internet]. [diunduh 2018 Nov 14]. Tersedia pada: http://dspace.bu.ac.th/bitstream/123456789/519/1/siri_maie.pdf.

Moon, Y., \& Quelch, J. (2015). Statbucks : Delivering Customer Service [internet]. [diunduh 2018 Nov 23 ]. Tersedia pada: http://www.academia.edu/download/44207169/C_Starbucks_Delivering_Cust.pdf.

Mulyono, B. H., Yoestini, Nugraheni, \& Kamal, M. (2007). Analisis Pengaruh Kualitas Produk dan Kualitas Layanan Terhadap Kepuasan Konsumen (Studi Kasus Pada Perumahan Puri Mediterania Semarang). Jurnal Studi Manajemen \& Organisasi [internet]. [diunduh 2018 Okt 3]. Tersedia pada: http://eprints.undip.ac.id/18008/.

Nalurita, S., Asmarantaka, R. W., \& Jahroh, S. (2014). Analisis Dayasaing dan Strategi Pengembangan Agribisnis Kopi Indonesia. Jurnal Agribisnis Indonesia, 2(1), 63-74. Diakses dari https://doi.org/10.29244/jai.2014.2.1.63-74.

Remiasa, M., \& Lukman, Y. (2008). Analisis Persepsi Pelanggan Terhadap Kualitas Layanan Coffee Shop Asing dan Coffee Shop Lokal. Jurnal Manajemen Perhotelan [internet]. [diunduh 2018 Okt 7]. Diakses pada: http://ced.petra.ac.id/index.php/hot/article/view/16752

Basrah S., \& Arifin, S. (2012). Pengaruh Kualitas Produk dan Kualitas Layanan Terhadap Kepuasan Konsumen dan Minat Beli Pada ranch Mart. Jurnal Riset Manajemen Sains

Indonesia, 03, 1-22. [diunduh 2018 Mar 5]. Diakses pada: http://journal.unj.ac.id/unj/index.php/jrmsi/article/view/766. 
Sara, S., Sebayang, T., \& Emalisa. (2013). Analisis Kepuasan Konsumen Gerai Kopi di Kota Medan dan Faktor-Faktor Yang Memengaruhinya. [internet]. [diunduh 2018 Okt 7]. Tersedia pada: https://jurnal.usu.ac.id/ceress/article/view/8063.

Sarwono, J. (2010). Pengertian Dasar Structural Equation Modeling (SEM) [Internet]. [diunduh 2018 Mar 4]. Diakses pada:

http://ejournal.ukrida.ac.id/ojs/index.php/IMB/article/viewFile/576/563.

Sofyan, I. L., Pradanawati, A., \& Nugraha, H. S. (2013). Pengaruh Fasilitas dan Kualitas Pelayanan Terhadap Loyalitas, Melalui Kepuasan Konsumen Sebagai Variabel Interving Pada Star Clean Car Wash Semarang. Diponegoro Journal of Social and Politic [Internet]. [diunduh 2018 Mar 3]. Diakses pada:

https://ejournal3.undip.ac.id/index.php/jiab/article/view/2505.

Terry, \& George, R. (2003). Dasar-Dasar Manajemen. Jakarta: Bina Aksara.

Validnews.co. (2017). Potensi Kopi Indonesia Dalam Gaya Hidup Masa Kini [Internet]. [diunduh 2018 Maret 10]. Diakses pada: http://validnews.co/POTENSI-KOPI-INDONESIADALAM-GAYA-HIDUP-MASA-KINI-SZJ.

Yu, H., \& Fang, W. (2009). Relative Impacts From Product Quality, Service Quality, and Experience Quality on Customer Perceived Value and Intention To Shop For The Coffee Shop Market. Journal Total Quality Management and Business Excellence [Intenet]. [diunduh 2018 Mar 28]; 20 : 1273-1285. Diakses pada:

https://www.tandfonline.com/doi/abs/10.1080/14783360802351587. 